\title{
Pengembangan Strategi Pelayanan Perijinan Impor Produk Hortikultura Berbasis Teknologi Informasi di Kementerian Perdagangan
}

\author{
Development of Strategy for Horticulture Products Import Licencse Services Based on Information \\ Technology In Ministry of Trade
}

\author{
Deden Taufik Komara ${ }^{*}$, Musa Hubeis ${ }^{2 \#}$, Muhammad Syamsun $^{2 \#}$ \\ ${ }^{1}$ Kementerian Perdagangan Republik Indonesia, Jakarta \\ 2Departemen Manajemen, Fakultas Ekonomi Manajemen Institut Pertanian Bogor \\ Jl. Lingkar Kampus, Gedung FAPERTA Wing 2 Level 5 \\ Kampus IPB Darmaga Bogor
}

\begin{abstract}
ABSTRAK
Perjanjian kerja sama perdagangan memberikan mandat kepada setiap anggota Organisasi Peragangan Dunia (WTO) termasuk Indonesia, untuk menyederhanakan proses perdagangan dengan tujuan memfasilitasi arus perdagangan barang antar negara. Inatrade adalah sistem berbasis teknologi yang dibangun oleh Kementerian Perdagangan yang bertujuan menyediakan jasa ekspor dan/atau impor dengan lebih cepat dan transparan. Dengan maksud untuk menentukan efektifitas pelayanan Inatrade, diperlukan identifikasi faktor dominan, aktor, dan indikator yang berpengaruh kepada peningkatan kualitas pelayanan. Penelitian ini bertujuan untuk mengetahui kondisi dari pelayanan perijinan impor produk hortikultura, mengidentifikasi faktor, aktor, dan indikator dominan yang mempengaruhi pelayanan dan menyusun strategi yang diperlukan untuk meningkatkan kualitas dari pelayanan perijinan di Kemeterian Perdagangan. Analisis dilakukan dengan menggunakan alat analisis Matriks Evaluasi Faktor Internal (IFE), Matriks Evaluasi Faktor Eksternal (EFE), Matriks SWOT dan Proses Analisis Hirarki (AHP). Dari hasil analisis dapat diambil kesimpulan bahwa mekanisme perijinan terpadu berbasis IT serta monitoring \& evaluasi sistem secara berkala termasuk aspek sistem, sumber daya manusia berbasis manusia merupakan strategi terbaik untuk meningkatkan kualitas pelayanan.
\end{abstract}

Kata kunci: perijinan impor, produk hortikultura, strategi, teknologi informasi

\section{ABSTRACT}

Trade Facilitation Agreement mandates each member of the World Trade Organization (WTO), including Indonesia, to simplify the trade system in order to facilitate trade flows between countries. Inatrade is an information technology-based system that was built by the Ministry of Trade that aims to provide services of export and/or import procedure fastrer and more transparent. In order to determine the effectiveness of Inatrade services, it is necessary to identify the dominant factors, actors, and indicators that influence to the improvement of the service quality. This study aims to determine the conditions of service horticultural products import license, to identify the dominant factors, actors, and indicators which influence services, and to formulate strategies needed to improve the quality of licensing services at the Ministry of Trade. The research used analytical tools of Internal Factor Evaluation Matrix (IFE), External Factor Evaluation Matrix (EFE), SWOT and Analytical Hierarchy Process (AHP). Based on the result analiysis it was concluded that the licensing mechanism based integrated information technology and monitoring and evaluation system regularly including aspects of the systems, human resources and legal basis as a best strategy to improve the quality of services.

Key words: horticultural products, import license, information technology, strategy

Korespondensi:

*) Jl. Raya Cifor Perumahan Taman Firdaus Blok B No. 9 Kelurahan Situgede, Bogor; e-mail: deden.komara@kemendag.go.id 


\section{PENDAHULUAN}

Kegiatan ekspor dan impor merupakan salah satu bentuk transaksi ekonomi yang dilakukan oleh suatu negara dengan negara lain, baik secara perorangan, kelompok, maupun pemerintah. Aktivitas tersebut dikenal dengan istilah perdagangan internasional. World Trade Organization (WTO) merupakan lembaga internasional yang mengatur sistem perdagangan secara multilateral bagi setiap negara anggotanya, termasuk Indonesia. Setiap anggotanya diberi mandat untuk menghilangkan atau mengurangi setiap hambatan (barrier), baik dalam bentuk proteksi tarif maupun non tarif, sehingga dapat memperlancar arus perdagangan internasional.

Dalam rangka memperlancar arus perdagangan, salah satu langkah yang diambil pemerintah Indonesia adalah dengan melakukan penyederhanaan prosedur di bidang kepabeanan berbasis sistem informasi yang dikenal dengan Indonesia National Single Window (INSW). Kebijakan ini diatur dalam Peraturan Presiden Nomor 10 Tahun 2008 tentang Penggunaan Sistem Elektronik dalam Kerangka Indonesia Nasional Single Window.

Penyederhanaan prosedur dan penggunaan teknologi informasi (TI) dalam penerbitan perijinan merupakan bentuk fasilitas perdagangan sebagaimana dimandatkan dalam Artikel VIII GATT (WTO, 1999). Pada artikel tersebut dinyatakan bahwa setiap anggota mengakui perlunya adanya pengurangan ketentuan ekspor dan impor dalam rangka penyederhanaan persyaratan dokumen ekspor dan impor. Dalam hal ini, penerapan Single Window yang berpedoman pada penyederhanaan prosedur ekspor impor, kesesuaian dengan standard dan praktek perdagangan internasional, dan juga penerapan teknologi informasi untuk otomasi bertujuan untuk mengurangi biaya yang timbul dalam proses perdagangan internasional terutama antara pelaku bisnis dengan instansi pemerintah yang terkait (Grainger, 2007). Inisiatif dan konsep mengenai Single Window sendiri telah dianjurkan oleh Perserikatan Bangsa Bangsa sejak tahun 2005 karena melihat banyaknya keuntungan yang dapat diperoleh suatu negara dengan mendirikan Single Window (McMaster, 2006).

Dukungan Kementerian Perdagangan sebagai instansi pemerintah yang tugas dan fungsinya menangani ekspor dan impor terhadap pengembangan INSW, telah meluncurkan sistem perijinan perdagangan berbasis TI yang dikenal dengan
Inatrade. Dengan adanya Inatrade, diharapkan pelayanan perijinan ekspor dan/atau impor di Kementerian Perdagangan menjadi lebih cepat dan transparan, tanpa harus ada lagi pertemuan tatap muka.

Kementerian Perdagangan telah menerbitkan beberapa pengaturan di bidang impor, diantaranya kebijakan impor beras, gula, hewan dan produk hewan serta produk hortikultura. Studi ini memfokuskan pada aturan mengenai impor produk hortikultura meliputi aspek perijinan impor, rekomendasi impor dan proses kepabeanan (custom clearance) di Bea dan Cukai. Alasan dipilihnya aturan mengenai produk hortikultura tersebut dikarenakan aturan tersebut baru dikeluarkan tahun 2012 melalui Peraturan Menteri Perdagangan No. 30/M-DAG/PER/5/2012 tentang Ketentuan Impor Produk Hortikultura (telah diubah beberapa kali terakhir dengan Peraturan Menteri Perdagangan No. 47/MDAG/PER/8/2013) dan rentan terhadap resistensi ${ }^{4}$ dari para pelaku (terutama importir) di dalam penerapannya.

Berdasarkan Peraturan Menteri Perdagangan tersebut, perusahaan yang akan melakukan impor harus memiliki penetapan sebagai Importir Terdaftar (IT) dan Persetujuan Impor (PI) bagi importir umum (trader) dan/atau pengakuan sebagai Importir Produsen (IP) bagi importir produsen/industri yang membutuhkan bahan baku asal impor. Semua ketentuan tersebut dikelola oleh Kementerian Perdagangan melalui sistem Inatrade.

Berdasarkan temuan awal, diperoleh informasi bahwa jumlah waktu rataan yang dibutuhkan untuk menyelesaikan dokumen impor produk holtukultura melebihi waktu janji layanan. Aturan mengenai janji layanan proses perijinan sesuai dengan Peraturan Menteri Perdagangan No. 40/M-DAG/PER/10/2010 tentang Jenis Perijinan Ekspor dan Impor, Prosedur Operasi Standar (Standard Operating Procedure) dan Tingkat Layanan (Service Level Arrangement) dengan Sistem Elektronik melalui Inatrade dalam Kerangka INSW. Peraturan mengenai janji layanan saat ini telah diubah beberapa kali

\footnotetext{
4 Berdasarkan hasil diskusi terbatas dengan beberapa stakeholder, diketahui bahwa salah satu bentuk resistensi dari para importir adalah timbulnya biaya tambahan dalam penyesuaian dokumen dan persyaratan dalam melakukan impor. Selain itu para importir juga mengeluhkan adanya kerugian pada proses awal penerapan kebijakan tersebut.
} 
terakhir dengan Peraturan Menteri Perdagangan No. 53/M-DAG/PER/9/2014 tanggal 2 September 2014 tentang Unit Pelayanan Terpadu Perdagangan (UPTP). Perbandingan waktu yang dibutuhkan untuk memproses perijinan impor produk hotikultura dan janji layanan dapat dilihat pada pada Tabel 1.

Dari hasil temuan tersebut, dapat dikatakan bahwa penerapan program Inatrade belum optimal bila dibandingkan dengan target tingkat layanan (Service Level Arrangement). Dalam rangka meningkatkan pelayanan, maka diperlukan pemetaan masalah secara mendalam dan penyusunan alternatif strategi yang dapat digunakan untuk meningkatkan pelayanan perijinan impor produk hortikultura berbasis TI di Kementerian Perdagangan.

Tabel 1. Jumlah waktu rataan yang dibutuhkan untuk pembuatan IT, PI, dan IP

\begin{tabular}{cccc}
\hline & $\begin{array}{c}2012 \\
\text { Semester II } \\
\text { (hari) }\end{array}$ & $\begin{array}{c}2013 \\
\text { Semester I } \\
\text { (hari) }\end{array}$ & $\begin{array}{c}\text { Service Level } \\
\text { Arrangement/ } \\
\text { SLA (hari) }\end{array}$ \\
\hline IT & 31,48 & 21,87 & 8 \\
PI & 9,68 & 5,66 & 2 \\
IP & 17,29 & 11,59 & 2 \\
\hline
\end{tabular}

Sumber: Database Inatrade (2013) diolah.

Berdasarkan uraian di atas, maka penelitian ini bertujuan untuk mengetahui kondisi pelayanan ijin impor di Kementerian Perdagangan, khususnya perijinan produk hortikultura secara menyeluruh. Tujuan lain daari penelitian ini adalan mengidentifikasi faktor, aktor yang berpengaruh secara dominan serta tujuan yang ingin di capai dalam rangka peningkatan mutu pelayanan perijinan yang diterapkan Kementerian Perdagangan. Dari dua hal tersebut diharapkan dapat merumuskan strategi peningkatan mutu pelayanan perijinan terbaik yang dapat diterapkan oleh Kementerian Perdagangan, khususnya produk hortikultura.

\section{METODE PENELITIAN}

Tahapan awal penelitian dimulai dengan identifikasi faktor internal (kekuatan, kelemahan) dan faktor eksternal (peluang, ancaman) yang diperoleh melalui studi literatur, hasil kuesioner, serta diskusi dengan pakar. Untuk mengetahui karakteristik sistem Inatrade yang terkait dengan perijinan impor hortikultura melalui pengamatan dan indepth interview dengan pihak-pihak yang terkait yang telah dipilih melalui purposive sampling

Tahap selanjutnya adalah analisis lingkungan internal dan eksternal dengan menggunakan Internal Factor Evaluation Matrix (IFE), External Factor Evaluation Matrix (EFE), tahap penggabungan dengan matriks internal eksternal (IE) serta pencocokan alternatife stategi dengan matriks Strengths, Weaknesses, Opportunities, and Threats (SWOT). Daftar alternatif stategi selanjutnya dinilai prioritasnnya dengan menggunakan Analytical Hierarchy Process (AHP). Secara skematis, kerangka pemikiran dapat dilihat pada Gambar 1.

Internal Factor Evaluation Matrix (IFE) Pelayanan Perijinan Impor Produk Hortikultura berasal dari hasil pembobotan dan peratingan faktor internal dengan melihat aspek kekuatan dan kelemahan. Nilai rating berasal dari nilai rataan pakar yang bernilai 3 dan 4 untuk aspek kekuatan; nilai 1 dan 2 untuk aspek kelemahan. Untuk nilai bobot tiap faktor, masing-masing pakar diminta melakukan perbandingan berpasangan antar faktor-faktor internal yang ada untuk menentukan tingkat kepentingan faktor tersebut dalam bentuk persen apabila dibandingkan antara satu dan faktor lainnya.

External Factor Evaluation Matrix (EFE) Pelayanan Perijinan Impor Produk Hortikultura berasal dari hasil pembobotan dan peratingan faktor eksternal dengan melihat aspek peluang dan ancaman. Nilai rating berasal dari nilai rataan pakar yang bernilai 1 hingga 4 . Untuk nilai bobot tiap faktor, masing-masing pakar diminta melakukan perbandingan berpasangan antar faktor-faktor internal yang ada untuk menentukan tingkat kepentingan faktor tersebut dalam bentuk persen, apabila dibandingan antara satu dan faktor lainnya.

Hasil skor dari matriks IFE dan EFE akan menentukan posisi dalam matriks IE. Matriks ini memposisikan suatu organisasi dalam tampilan sebuah sel (Gambar 2). Total skor bobot IFE berada pada sumbu $\mathrm{x}$ dan total skor EFE pada sumbu y. Matriks IE dibagi menjadi tiga daerah utama yang mempunya implikasi stategi yang berbeda, yaitu:

1. Daerah I meliputi sel I, II atau IV digambarkan dengan daerah tumbuh dan berkembang (grow and guild);

2. Daerah II meliputi sel III,V atau VII termasuk daerah menjaga dan mempertahankan (hold and maintain); 
3. Daerah III meliputi sel VI,VIII atau IX adalah daerah panen (harvest or divestasi).

Tahap selanjutnya menyusun matriks SWOT (Strengths, Weaknesses, Opportunities, and Threats). Matriks SWOT digunakan untuk mencocokan faktor internal dan ekternal. Pengembangan stategi pada matriks SWOT dilakukan berdasarkan hasil dari matriks IE. Setelah diketahui kondisi masing-masing faktor internal dan eksternal, maka dilanjutkan dengan perumusan strategi alternatif dengan menggunakan AHP yang dikembangkan oleh Saaty (1993).

Pihak yang menjadi target responden adalah 2 orang perwakilan dari Direktorat Impor yang menangani impor produk hortikultura, 2 orang perwakilan dari Direktorat Fasilitasi Ekspor dan Impor yang menangani pelayanan perijinan inatrade dan INSW, satu orang perwakilan dari Direktorat Jenderal Pengolahan dan Pemasaran Hasil Pertanian Kementerian Pertanian yang menangani impor hortikultura, serta satu orang pakar dari Direktorat Jenderal Bea dan Cukai Pusat yang pernah turut membangun sistem INSW.

Penelitian dilakukan seluruhnya di Jakarta pada bulan November 2013-Maret 2014.

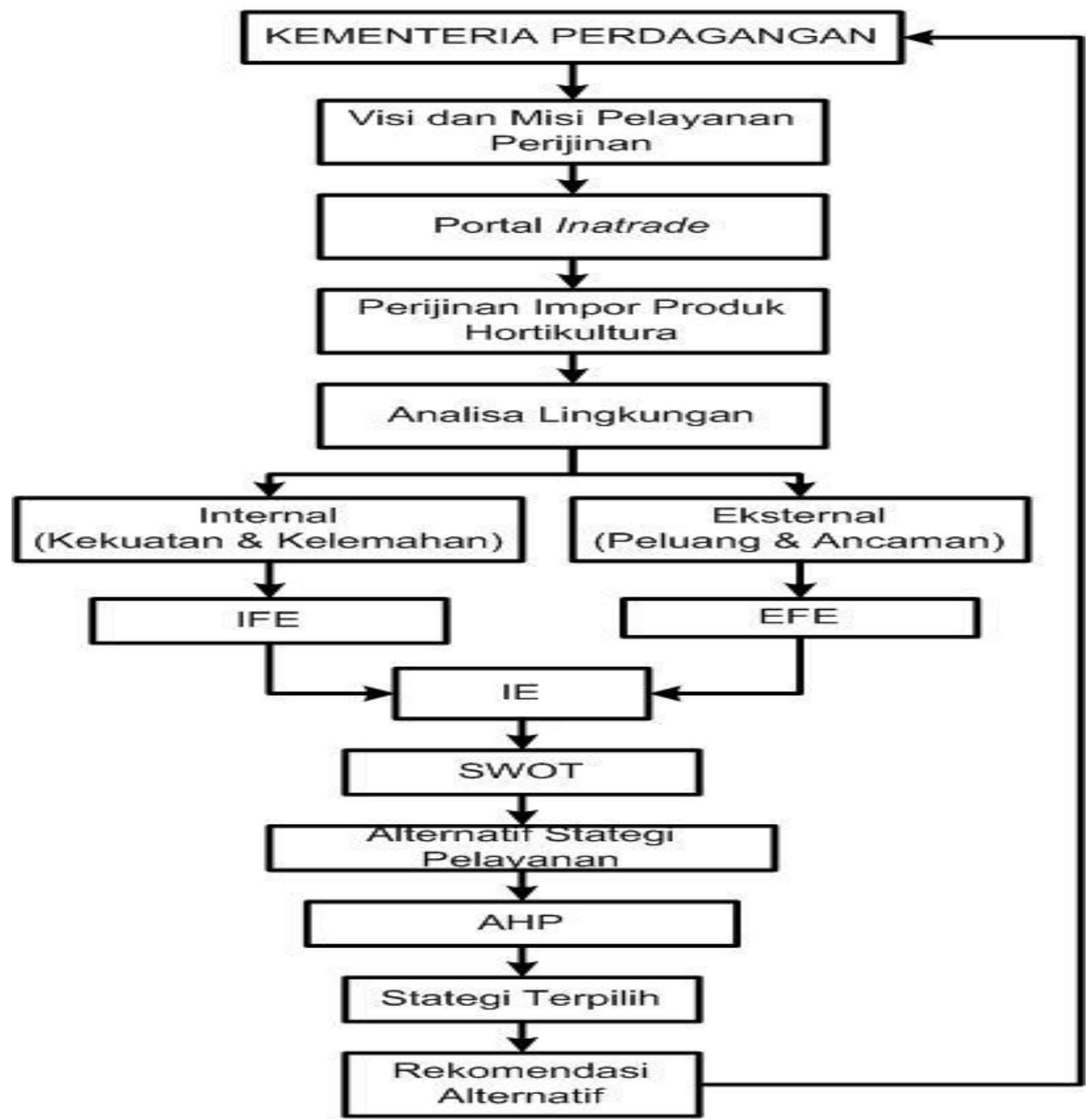

Gambar 1. Diagram alir kerangka pemikiran 


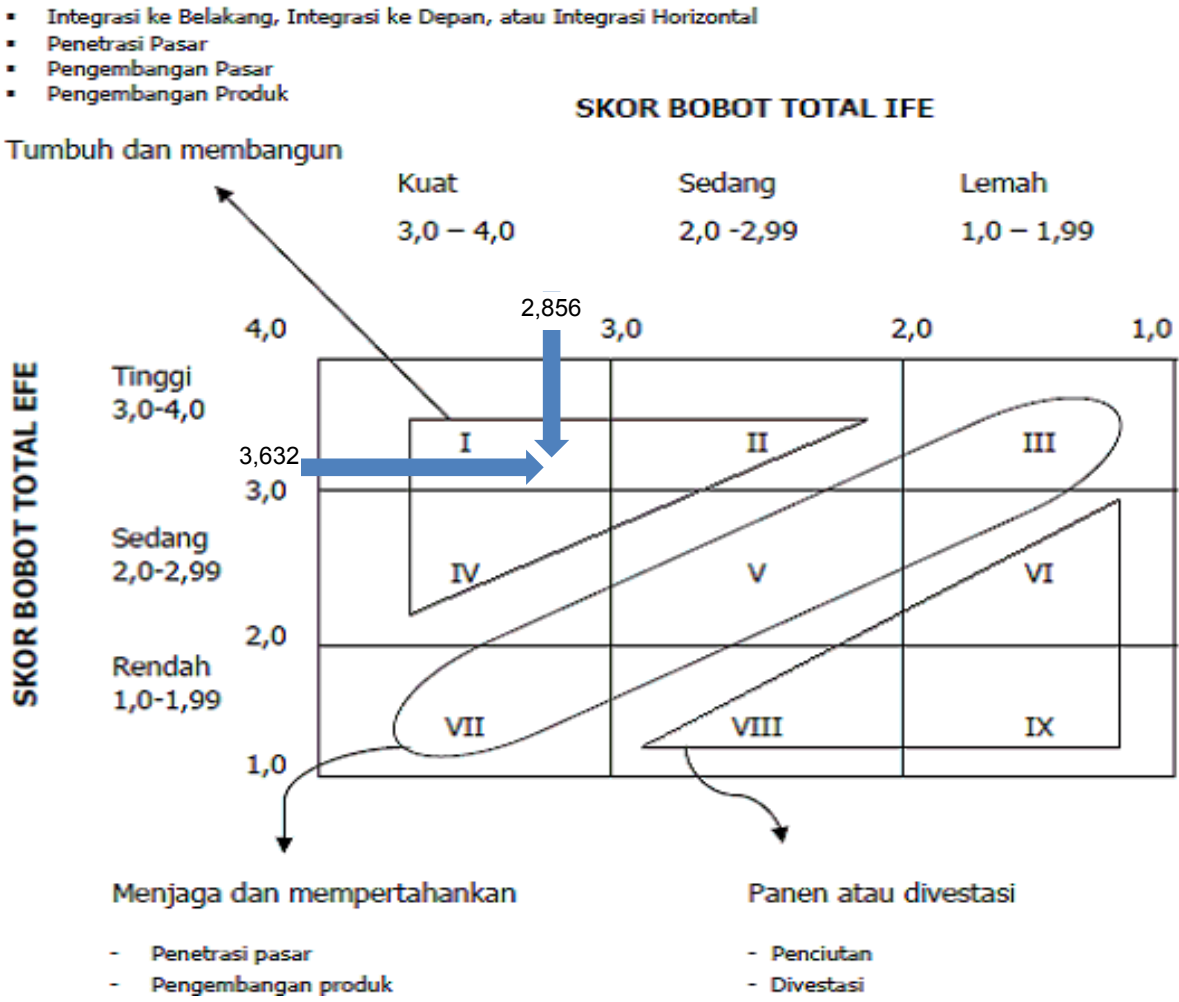

Gambar 2. Matriks internal eksternal pelayanan perijinan impor produk hortikultura

\section{HASIL DAN PEMBAHASAN}

\section{Profil Singkat Inatrade}

Kementerian Perdagangan terus berupaya meningkatkan pelayanan publik khususnya pelayanan di bidang perdagangan luar negeri. Salah satu langkah stategis yang dilakukan adalah dengan mengembangkan sistem perijinan secara elektronik yang diberi nama Inatrade yang mulai beroperasi sejak tanggal 17 Desember 2007. Tujuan dari pengembangan Inatrade untuk mendorong kinerja pelayanan perdagangan, baik ekspor maupun impor serta guna membantu kelancaran arus barang.

Bagi pelaku usaha yang telah memiliki hak akses, diberikan kesempatan untuk dapat diberikan fasilitas pelayanan perijinan perdagangan secara online, melalui web site http://inatrade.kemendag.go.id. Berdasarkan data base dari inatrade diketahui bahwa hingga bulan juni 2015 sudah ada 11.772 perusahaan yang memiliki hak akses untuk mendapatkan pelayanan perdagangan secara online. Sejak tanggal 2 Desembr 2014 sudah ada 96 jenis perijinan, baik impor maupun ekspor yang dapat dilayani secara online/Mandatory Online. (inatrade, 2015).

\section{Analisa Matriks IFE Pelayanan Perijinan Impor Produk Hortikultura}

Berdasarkan dari Tabel 2 dapat dilihat faktor-faktor internal yang terdiri atas kekuatan dan kelemahan dari sistem perijinan menggunakan inatrade. Faktor kekuatan terdiri dari kepemimpinan transformasional, sistem yang mudah, cepat, akurat, transparan dan sistem yang selalu update serta penurunan biaya. Faktor-faktor kelemahan data kami data meliputi sumber daya penunjang yang kurang memadai, terdapat data/dokumen impor yang beragam, resistensi internal terhadap perubahan pola perijinan, kurangnya, sosialisasi sistem perijinan online, remunerasi yang masih rendah dan alokasi anggaran yang kaku.

Berdasarkan Tabel 2, matriks IFE menghasilkan skor bobot total 2,856. Skor bobot total lebih dari 2,5 dalam skala 1-4 (bobot total 2,856) mengindikasikan posisi internal yang cukup kuat, sudah mempunyai strategi yang baik dalam mengantisipasi kelemahan eksternal yang ada (David, 2009).

\section{Analisa Matriks EFE Pelayanan Perijinan Impor Produk Hortikultura}

Tabel 3 dapat dilihat analisis eksternal yang terdiri dari faktor peluang dan faktor ancaman yang paling berpengaruh terhadap penentuan 
strategi. Faktor peluang yang dapat didata adalah pengurusan dokumen impor cepat, pengajuan perijinan dapat dilakukan di mana saja, tahapan proses perijinan dapat di monitor, proses custom and clearance di bea dan cukai dapat dilakukan lebih cepat, dan peluang untuk menurunkan biaya importasi. Faktor-faktor ancaman terdiri dari kurangnya koordinasi antar instansi yang terlibat, kurangnya integrasi elemen data impor antara kementerian terkait, importir kurang paham penggunaan sistem inatrade, keamanan data dan informasi MOU dengan instansi teknis penunjang inatrade yang akan berakhir.

Dari Matrik EFE matrix diperoleh total skor 3,62 mengindikasikan posisi bahwa posisi sistem lebih dari cukup kuat dalam mengantisipasi perubahan lingkungan eksternal, dalam upaya pemanfaatan peluang, serta mengantisipasi ancaman dan masih cukup ruang bagi perbaikan dalam operasi.

\section{Analisis Matriks IE Pelayanan Perijinan Impor Produk Hortikultura}

Matriks IE menggabungkan skor dari matriks IFE dan EFE untuk mendapatkan posisi sel pelayanan perijinan impor produk hortikultura berbasis teknologi informasi di Kementerian Perdagangan (David, 2009).
Penggabungan matriks IFE sebesar 2,856 dan EFE sebesar 3,632 menempatkan posisi di sel I. Menurut David (2009), organisasi yang termasuk dalam sel I, II dan IV cocok untuk melakukan strategi tumbuh dan membangun (grow and build). Strategi yang dapat ditempuh oleh perusahaan antara lain strategi intensif (penetrasi pasar, pengembangan produk) atau strategi integratif (integrasi).

\section{Matriks SWOT}

Berdasarkan matriks SWOT sesuai dengan Tabel 4, dapat dirumuskan beberapa startegi untuk diverifikasi oleh pakar. Strategi yang dihasilkan adalah:

1. Mekanisme terpadu berbasis TI.

2. Monitoring dan evaluasi sistem secara berkala baik dari aspek sistem, SDM dan landasan hukum;

3. Perbaikan pelayanan (sistem) untuk mempermudah pihak pengguna (user friendly);

4. Standardisasi data/dokumen impor/ekspor sesuai standar pertukaran data elektronik

5. Sosialisasi perkembangan secara rutin.

6. Peningkatan program reward and punisment berbasis kinerja.

Tabel 2. Internal Factor Evaluation Matrix

\begin{tabular}{|c|c|c|c|c|}
\hline & Rating IFE & Rating (R) & Bobot (B) & $\mathbf{R x B}$ \\
\hline \multicolumn{5}{|c|}{ Kekuatan: } \\
\hline 1 & Kepemimpinan transformasional & 3,6 & 0,106 & 0,382 \\
\hline 2 & Ketepatan & 4,0 & 0,090 & 0,360 \\
\hline 3 & Sistem yang terus menerus di update & 4,0 & 0,089 & 0,356 \\
\hline 4 & Kemudahan & 3,8 & 0,091 & 0,346 \\
\hline 5 & Kecepatan & 3,8 & 0,085 & 0,323 \\
\hline 6 & Transparan/auditable & 3,8 & 0,071 & 0,270 \\
\hline 7 & Penurunan biaya & 3,6 & 0,047 & 0,169 \\
\hline \multicolumn{5}{|c|}{ Kelemahan: } \\
\hline 1 & Resistensi internal & 1,8 & 0,062 & 0,112 \\
\hline 2 & SDM yang masih harus menyesuaikan diri & 1,8 & 0,057 & 0,103 \\
\hline 3 & Standarisasi data/dokumen impor & 1,6 & 0,064 & 0,102 \\
\hline 4 & Infrastruktur di unit pelayanan kurang maksimal & 1,6 & 0,045 & 0,072 \\
\hline 5 & Kurangnya sosialisasi & 1,6 & 0,043 & 0,069 \\
\hline 6 & Remunerasi & 1,2 & 0,053 & 0,064 \\
\hline 7 & Kekakuan alokasi anggaran & 1,2 & 0,045 & 0,054 \\
\hline 8 & Kurangnya tenaga konsultasi importir & 1,4 & 0,031 & 0,043 \\
\hline \multirow[t]{2}{*}{9} & Kelembagaan pelayanan perijinan yang masih ad hoc & 1,4 & 0,022 & 0,031 \\
\hline & & & 1,000 & 2,856 \\
\hline
\end{tabular}


Tabel 3. External Factor Evaluation Matrix

\begin{tabular}{|c|c|c|c|c|}
\hline & Rating EFE & Rating (R) & Bobot (B) & $\mathbf{R x B}$ \\
\hline \multicolumn{5}{|c|}{ Peluang: } \\
\hline 1. & Importir mendapatkan kepengurusan ijin secara cepat & 3,8 & 0,187 & 0,7106 \\
\hline 2. & Proses custom and clearance yang lebih cepat & 3,8 & 0,162 & 0,6156 \\
\hline 3. & Importir dapat memantau tahapan perijinan & 4,0 & 0,132 & 0,528 \\
\hline 4. & Pengajuan ijin yang dapat dilakukan dimana saja & 3,8 & 0,116 & 0,4408 \\
\hline 5. & Terjadi penurunan biaya dari sisi importir & 3,8 & 0,064 & 0,2432 \\
\hline \multicolumn{5}{|c|}{ Ancaman: } \\
\hline 1. & $\begin{array}{l}\text { Kurangnya integrasi data dengan kementerian lain dalam } \\
\text { melakukan perijinan }\end{array}$ & 3,4 & 0,081 & 0,2754 \\
\hline 2. & Kurangnya koordinasi dengan kementerian terkait & 3,2 & 0,068 & 0,2176 \\
\hline 3. & $\begin{array}{l}\text { Terdapat importir yang kurang paham mengenai } \\
\text { penggunaan inatrade }\end{array}$ & 3,4 & 0,054 & 0,1836 \\
\hline 4. & $\begin{array}{l}\text { Kebocoran data sistem informasi oleh staf out source yang } \\
\text { disewa untuk kepentingan pribadi }\end{array}$ & 3,2 & 0,047 & 0,1504 \\
\hline 5. & Ketidakstabilan jaringan dari pihak importir & 3,0 & 0,036 & 0,108 \\
\hline 6. & Adanya hacker yang dapat membobol sistem & 3,2 & 0,026 & 0,0832 \\
\hline \multirow{2}{*}{\multicolumn{2}{|c|}{$\begin{array}{l}\text { 7. MOU dengan instansi teknis penunjang inatrade yang } \\
\text { akan berakhir dalam waktu dekat }\end{array}$}} & 2,8 & 0,027 & 0,0756 \\
\hline & & & 1,000 & 3,632 \\
\hline
\end{tabular}

Tabel 4. Matriks SWOT

\begin{tabular}{|c|c|c|}
\hline Faktor Eksternal & $\begin{array}{ll}\text { Peluang }(\mathbf{O}) \\
\text { 1. Pengurusan dokumen } \\
\text { impor cepat, secara online } \\
\text { dan dapat di monitor } \\
\text { tahapan prosesnya. } \\
\text { 2. Proses custom and clearance } \\
\text { di Bea dan cukai lebih cepat } \\
\text { 3. Efisiensi biaya importasi }\end{array}$ & $\begin{array}{l}\text { Ancaman }(\mathrm{T}) \\
\begin{array}{l}\text { 1. } \\
\text { integrangnya koordinasi dan } \\
\text { terkait }\end{array} \\
\text { 2. Importir kurang paham pengguna- } \\
\text { an sistem inatrade } \\
\text { 3. Keamanan data dan informasi } \\
\text { 4. MOU dengan instansi teknis penun- } \\
\text { jang inatrade yang akan berakhir } \\
\text { dalam waktu dekat }\end{array}$ \\
\hline $\begin{array}{l}\text { Kekuatan (S) } \\
\text { 1. Kepemimpinan transformasional } \\
\text { 2. Sistem yang mudah, cepat, akurat } \\
\text { dan transparan serta selalu update } \\
\text { 3. Penurunan biaya }\end{array}$ & \begin{tabular}{l}
\multicolumn{1}{c}{ Strategi (SO) } \\
Peningkatan program reward and \\
punisment berbasis kinerja \\
$(\mathrm{S} 1, \mathrm{~S} 2, \mathrm{O} 1, \mathrm{O} 2, \mathrm{O} 3)$
\end{tabular} & \begin{tabular}{ll}
\multicolumn{1}{c}{ Strategi (ST) } \\
- & Sosialisasi secara rutin $(\mathrm{S} 1, \mathrm{~S} 3, \mathrm{~T} 1, \mathrm{~T} 2)$ \\
& Perbaikan sistem secara berkala \\
& sehingga mudah digunakan oleh \\
& pihak terkait $(\mathrm{S} 2, \mathrm{~T} 2)$ \\
\end{tabular} \\
\hline $\begin{array}{l}\text { Kelemahan }(\mathbf{W}) \\
\text { 1. Resistensi internal terhadap } \\
\text { perubahan pola perijinan } \\
\text { 2. Keanekaragaman data/dokumen } \\
\text { impor } \\
\text { 3. Sumber daya penunjang yang } \\
\text { kurang memadai } \\
\text { 4. Kurangnya sosialisasi sistem } \\
\text { perijinan online } \\
\text { 5. Remunerasi } \\
\text { 6. Kekakuan alokasi anggaran }\end{array}$ & $\begin{array}{l}\quad \text { Strategi (WO) } \\
\text { Standarisasi data/dokumen } \\
\text { impor/ekspor sesuai dengan } \\
\text { pertukaran data eletronik } \\
\text { (W2,O1,O2,O3) }\end{array}$ & \begin{tabular}{l}
\multicolumn{1}{c}{ Strategi $(\mathbf{W T})$} \\
- $\quad$ Mekanisme perijinan berbasis TI \\
(W2,W6,T1) \\
Monitoring dan evaluasi sistem \\
secara berkala, baik dari aspek \\
sistem, SDM dan landasan hukum \\
$(\mathrm{W} 1, \mathrm{~W} 3, \mathrm{~W} 4, \mathrm{~W} 5, \mathrm{~W} 6, \mathrm{~T} 1, \mathrm{~T} 3, \mathrm{~T} 4)$
\end{tabular} \\
\hline
\end{tabular}

\section{Analisis Pengambilan Keputusan Menggunakan} AHP

Struktur hirarki strategi pelayanan perijinan impor produk hortikultura berbasis TI di Kementerian Perdagangan disusun oleh 4 level hirarki, antara lain:
1. Faktor yang memperngaruhi sasaran utama, yaitu organisasi dan SDM, biaya, sistem infrastruktur Inatrade dan alokasi anggaran.

2. Aktor yang terlibat untuk mencapai sasaran utama, yaitu Menteri Perdagangan, Direktur 
Jenderal Perdagangan Luar Negeri, Direktur (Direktur Impor dan Direktur Fasilitasi Ekspor dan Impor) dan tim pelaksana (kepala seksi di Direktorat Fasilitasi Ekspor dan Impor, Tim TI dari PT EDII dan petugas UPP).

3. Tujuan yang ingin dicapai, yaitu mendukung sistem perdagangan nasional dan internasional, mendukung upaya e-Government, menurunkan biaya dan mempercepat proses serta meningkatkan akurasi data perijinan impor.

4. Alternatif stategi yang diperoleh dari hasil analisa SWOT, antara lain mekanisme perijinan terpadu berbasis TI (S1), monitoring dan evaluasi sistem secara berkala, baik dari aspek sistem, SDM dan landasan hukum (S2), perbaikan pelayanan (sistem) untuk mempermudah pihak pengguna (user friendly) (S3), standardisasi data/dokumen impor sesuai standar pertukaran data elektronik (S4), sosialisasi perkembangan berkala (S5) dan peningkatan program reward and punisment berbasis kinerja (S6).

\section{Pengolahan Horizontal}

Pengolahan horizontal terdiri dari atas tiga tingkatan unsur, yaitu (1) tingkat kepentingan aktor terhadap faktor; (2) tingkat kepetingan tujuan terhadap aktor; (3) tingkat kepentingan strategi terhadap tujuan.

Tabel 5 menjelaskan tingkat kepentingan aktor terhadap faktor-faktor yang berperan dalam pengembangan sistem inatrade. Berdasarkan Tabel 5, Menteri adalah aktor yang paling berperan dalam pembenahan organisasi dan SDM, serta alokasi anggaran, Tim Teknis merupakan aktor yang yang penting dalam hal menurunkan biaya serta Dirjen merupakan aktor penting dalam hal pembenahan sistem infrastruktur inatrade.

Tabel 5. Unsur aktor pada tingkat ketiga

\begin{tabular}{lcccc}
\hline \multirow{2}{*}{ Aktor } & \multicolumn{4}{c}{ Faktor } \\
\cline { 2 - 5 } & $\begin{array}{c}\text { Organisasi } \\
\text { \& SDM }\end{array}$ & Biaya & $\begin{array}{c}\text { Sistem } \\
\text { Infrastruktur } \\
\text { Inatrade }\end{array}$ & $\begin{array}{c}\text { Alokasi } \\
\text { Anggaran }\end{array}$ \\
\hline Menteri & $\mathbf{0 , 4 2 5}$ & 0,220 & 0,292 & $\mathbf{0 , 4 5 7}$ \\
Dirjen & 0,301 & 0,227 & $\mathbf{0 , 3 0 2}$ & 0,263 \\
Direktur & 0,168 & 0,231 & 0,200 & 0,185 \\
Tim & 0,106 & $\mathbf{0 , 3 2 2}$ & 0,206 & 0,095 \\
Pelaksana & & & & \\
\hline
\end{tabular}

Guna menjalankan tugas membantu Presiden dalam penyelenggaraan urusan pemerintah di bidang perdagangan, Menteri Perdagangan memiliki kewenangan penuh dalam memimpin dan mengelola kementerian termasuk penyusunan organisasi, SDM serta alokasi anggaran sesuai dengan amanat dari Peraturan Presiden Nomor 48 tahun 2015 tentang Kementerian Perdagagangan.

Dalam struktur organisasi di Kementerian Perdagangan, Direktur Jenderal merupakan aktor yang paling berperan dalam menterjemahkan visi dan misi menteri ke dalam bentuk kegiatan kementeriana. Dirjen menjadi aktor yang bertanggung jawab dalam kegiatan teknis kementerian termasuk program perbaikan sistem infrastruktur inatrade.

Dalam tata kelola pelaksanaan pelayanan perijinan, tim teknis merupakan aktor berhadapan langsung dengan pelaku usaha jika terjadi permasalahan teknis di lapangan. Ketika ada hambatan teknis berupa data tidak terkirim ke INSW atau adanya nota penolakan dari Bea dan Cukai, sehingga pelayanan kepabeanan tidak dapat diproses lebih lanjut yang berpotensi menimbulkan biaya penumpukan dll, tim teknis harus siap memberikan pelayanan dan memberikan solusi jalan keluar terhadap permasalah tersebut.

Tabel 6 menjelaskan tingkat kepentingan tujuan khusus yang ingin dicapai dalam rangka pengembangan sistem inatrade di Kementerian Perdagangan. Berdasarkan hasil analisa dapat diketahui bahwa dengan berkembanganya sistem inatrade sebagian besar aktor (Menteri, Dirjen, dan Diretur Fasilitas Ekspor-Impor), memiliki tujuan yang sama, yaitu mendorong berkembangnya sistem perdagangan nasional dan internasional kearah yang lebih baik. Tim teknis lebih fokus pada tataran teknis yaitu hal yang lebih praktis yaitu terkait kecepatan dan akurasi proses perijinan

Tujuan stategis yang ingin dicapai pimpinan Kementerian Perdagangan pada setiap level tentunya memiliki tujuan yang sama yaitu mendorong berkembangnya sistem perdagangan nasional dan internasional kearah yang lebih baik, hal ini karena ketergantungan Indonesia pada perdagangan internasional sebagai mesin penggerak perekonomian nasional cukup besar (Safitriani, 2014). Berdasarkan hasil kajian dari Salomo (2007) menyatakan bahwa dalam jangka panjang ekspor berpengaruh signifikan terhadap pertumbuhan ekonomi Indonesia. Kenaikan Ekspor sebesar $1 \%$ cateris paribus, dalam jangka panjang akan meningkatkan Laju Pertumbuhan Ekonomi 0,30051\%.

Tujuan mempercepat proses serta meningkatkan akurasi data perijinan impor (T4), aktor 
yang paling berperan cukup di level teknis yaitu tim teknis.

Tabel 7 menunjukan bobot kepentingan alternatif-alternatif strategi yang mungkin untuk diambil terkait dengan tujuan-tujuan yang telah dipaparkan diatas. Guna mendukung tujuan mendukung sistem perdagangan nasional dan internasional, menurunkan biaya serta mempercepat proses serta meningkatkan akurasi data perijinan impor, alternatif strategi yang dipilih oleh pakar adalah mekanisme perijinan terpadu berbasis TI.

Berdasarkan McMaster (2006) teknologi komunikasi dan informasi merupakan kunci dalam fasilitasi perdagangan. Pemanfaatan teknologi komunikasi dan informasi dapat menguraingi kompleksitas perdagangan internasional sehingga dapat meminimalkan biaya transaksi perdagangan. Selain hal tersebut, manfaat lain yang diperoleh dari sistem tersebut adalah dapat meningkatkan keamanan perdagangan serta transparansi dalam rantai pasokan.
Dalam kaitannya dengan impor hortikultura, pemanfaatan teknologi infomasi membuat sistem administrasi dan prosedur perijinan impor menjadi lebih senderhana dan transparan baik yang berkaitan dengan Kementerian Pertanian, Badan POM, Kementerian Perdagangan hingga di Bea dan Cukai.

Di beberapa negara maju, konsep pemanfaatan teknologi informasi dalam fasilitas perdagangan internasional sudah berevolusi menjasi sebuah Single Window berupa portal layanan satu atap yang menyediakan gateway elektronik terpadu yang memungkinkan informasi perdagangan dan dokumen lain yang terkait dapat disampaikan hanya pada satu kali oleh eksportir, importir, broker pabean, freight forwarder, agen pengiriman dan pemain lain, di titik masuk tertentu. Informasi dan dokumen ini kemudian ditransmisikan ke Bea dan Cukai, karantina, perijinan, pelabuhan dan otoritas pemerintah lainnya, serta perusahaan asuransi, bank dan semua instansi swasta lainnya yang terlibat dalam perdagangan internasional.

Tabel. 6. Unsur tujuan pada tingkat keempat

\begin{tabular}{lcccc}
\multicolumn{1}{c}{ Tujuan/aktor } & Menteri & Dirjen & Direktur & $\begin{array}{c}\text { Tim } \\
\text { pelaksana }\end{array}$ \\
\hline Mendukung sistem perdagangan nasional dan internasional (T1) & $\mathbf{0 , 4 2 5}$ & $\mathbf{0 , 4 1 2}$ & $\mathbf{0 , 3 6 8}$ & 0,256 \\
Mendukung upaya e-Government (T2) & 0,311 & 0,257 & 0,250 & 0,173 \\
Menurunkan biaya (T3) & 0,111 & 0,111 & 0,120 & 0,152 \\
Mempercepat proses serta meningkatkan akurasi data perijinan & 0,155 & 0,220 & 0,263 & $\mathbf{0 , 4 1 9}$ \\
impor (T4) & & & &
\end{tabular}

Tabel 7. Unsur tujuan terhadap alternatif strategi

\begin{tabular}{|c|c|c|c|c|}
\hline Stategi/Tujuan & $\begin{array}{l}\text { Mendukung sistem } \\
\text { perdagangan nasional } \\
\text { dan internasional }\end{array}$ & $\begin{array}{c}\text { Mendukung } \\
\text { upaya e- } \\
\text { Government }\end{array}$ & $\begin{array}{l}\text { Menurun- } \\
\text { kan biaya }\end{array}$ & $\begin{array}{l}\text { Mempercepat proses } \\
\text { serta meningkatkan } \\
\text { akurasi data perijinan } \\
\text { impor }\end{array}$ \\
\hline 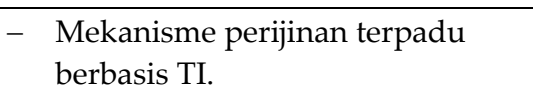 & 0,216 & 0,174 & 0,215 & 0,244 \\
\hline 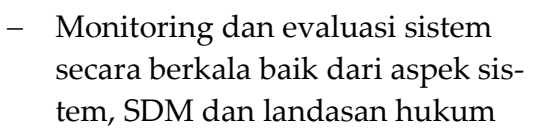 & 0,216 & 0,249 & 0,120 & 0,111 \\
\hline $\begin{array}{l}\text { - Perbaikan pelayanan (sistem) } \\
\text { untuk mempermudah pihak } \\
\text { pengguna (user friendly) }\end{array}$ & 0,172 & 0,198 & 0,215 & 0,238 \\
\hline $\begin{array}{l}\text { - Standardisasi } \\
\text { data/dokumenimpor/eksporsesua } \\
\text { i standar pertukaran data } \\
\text { elektronik }\end{array}$ & 0,177 & 0,181 & 0,144 & 0,197 \\
\hline $\begin{array}{l}\text { - Sosialisasi perkembangan secara } \\
\text { rutin }\end{array}$ & 0,116 & 0,105 & 0,211 & 0,112 \\
\hline $\begin{array}{l}\text { - Peningkatan program reward and } \\
\text { punisment berbasis kinerja }\end{array}$ & 0,103 & 0,092 & 0,095 & 0,099 \\
\hline
\end{tabular}


Berdasarkan Grainger (2007) bahwa penerapan Single Window yang berpedoman pada penyederhanaan prosedur ekspor impor, kesesuaian dengan standard dan praktek perdagangan internasional, dan juga penerapan teknologi informasi untuk mengurangi biaya yang timbul dalam proses perdagangan internasional terutama antara pelaku bisnis dengan instansi pemerintah yang terkait. Inisiatif dan konsep mengenai Single Window sendiri telah dianjurkan oleh Perserikatan Bangsa Bangsa sejak tahun 2005 karena melihat banyaknya keuntungan yang dapat diperoleh suatu negara dengan mengembangkan konsep Single Window (Mc.Master, 2006).

Guna mendukung strategi tersebut, tentunya tidak akan lepas dari pembenahan internal Kementerian Perdagangan baik di dalam kesiapan system informasi, kesiapan SDM yang akan menjalankannya serta dukungan perauran perundang-undangan. Oleh karena hal tersebut monitoring dan evaluasi sistem secara berkala baik dari aspek sistem, SDM dan landasan hukum, merupakan hal yang sangat penting guna mendukung tujuan-tujuan tersebut diatas.

\section{Pengolahan Vertikal}

a. Faktor

Berdasarkan hasil analisa AHP pada Tabel 8, faktor yang peling guna medukung strategi pengembangan pelayanan perijinan impor hortikultura berbasis TI di Kementerian Perdagangan adalah Organisasi dan SDM (F1) dengan bobot 0,399 dan alokasi anggaran (F4) dengan bobot 0,261 .

Tabel 8. Bobot faktor dan prioritas faktor yang paling berperan dalam strategi pengembangan pelayanan sistem inatrade secara vertikal

\begin{tabular}{ccc}
\hline Faktor & Bobot & Prioritas \\
\hline F1 & 0,399 & 1 \\
F4 & 0,261 & 2 \\
F3 & 0,235 & 3 \\
F2 & 0,105 & 4 \\
\hline
\end{tabular}

Organisasi atau kelembagaan merupakan hal penting dalam mengembangkan stategi untuk mencapai dengan pendekatan sistem. Dengan organisasi dan pengorganisasian yang baik, sumber daya manusia, sumber daya fisik dan sumber daya modal/keuangan dapat di sinkronisasi dan kombinasi dengan lebih baik guna mencapai tujuan dari Kementerian Perdagangan.
Selain hal tersebut di atas, dukungan sumber daya manusia yang baik juga menjadi hal yang mutlak guna menggerakkan strategi yang telah disusun guna menunjang pengembangan pelayanan perijinan impor hortikultura berbasis TI di Kementerian Perdagangan.

Selain faktor organisasi dan SDM, hal yang tidak dapat diacuhkan adalah alokasi anggaran yang cukup. Alokasi anggaran merupakan faktor penting guna memastikan berjalannya strategi pengembangan pelayanan perijinan impor hortikultura berbasis TI di Kementerian Perdagangan.

b. Aktor

Aktor paling penting yang dipilih responden guna mendukung Strategi Pengembangan Pelayanan Perijinan Impor Hortikultura Berbasis TI di Kementerian Perdagangan adalah A1 (Menteri) dengan bobot 0,380572, sedangkan aktor yang dinilai responden memiliki bobot paling kecil adalah A4 (tim teknis) dengan bobot 0,192197 (Tabel 9).

Tabel 9. Bobot dan prioritas aktor-aktor yang paling berperan dalam penyusunan strategi

\begin{tabular}{ccc}
\hline Aktor & Bobot & Prioritas \\
\hline A1 & 0,380572 & 1 \\
A2 & 0,283547 & 2 \\
A3 & 0,263890 & 3 \\
A4 & 0,192197 & 4 \\
\hline
\end{tabular}

Dalam hirarki kepemimpinan organisasi di Kementerian Perdagangan, Menteri menepati posisi paling atas dengan segala hak dan kewenangan yang dimilikinya sesuai dengan aturan perundang undangan. Menteri memiliki kewenangan dan tanggung jawab dalam pengelolan anggaran belanja negara kementerian hingga mentukan struktur organisasi kementerian. Dalam tata kelola pelayanan perijinan di Kementerian Perdagangan, komitmen menteri sebagai pimpinan puncak merupakan hal yang sangat penting karena akan dampak langsung kepada komitmen pemimpin unit yang ada di bawahnya.

Meskipun bobot tim teknis menempati posisi yang paling kecil, namun peran tim teknis dalam tataran implementatif kebijakan tidak dapat disebut kecil. Tim pengelola sistem inatrade/tim IT merupakan aktor terdepan yang berhadapan langsung dengan pelaku usaha jika terjadi permasalahan teknis di lapangan. Hambatan teknis biasa berupa data tidak terkirim 
ke INSW atau adanya nota penolakan dari Bea dan Cukai, sehingga pelayanan kepabeanan tidak dapat diproses lebih lanjut. Ketika ada permasalahan tersebut, tim teknis harus siap memberikan pelayanan dan memberikan solusi jalan keluar terhadap permasalah tersebut.

\section{c. Tujuan}

Berdasarkan hasil analisa AHP, tujuan yang paling penting untuk dituju dalam penyusunan Strategi Pengembangan Pelayanan Perijinan Impor Hortikultura Berbasis TI di Kementerian Perdagangan adalah T1 (mendukung sistem perdagangan nasional/internasional) dengan bobot 0,392747, sedangkan bobot yang paling rendah adalah T3 (menurunkan biaya) dengan bobot 0,116858 (Tabel 10). Kegiatan perdagangan merupakan penggerak utama dalam pembangunan perekonomian nasional yang dapat memberikan daya dukung dalam meningkatkan produksi dan memeratakan pendapatan serta memperkuat daya saing produk dalam negeri.

Tabel 10. Bobot dan prioritas tujuan yang ingin dicapai Kementerian Perdagangan

\begin{tabular}{ccc}
\hline Tujuan & Bobot & Prioritas \\
\hline T1 & 0,392747 & $\mathbf{1}$ \\
T2 & 0,269870 & 2 \\
T4 & 0,220693 & 3 \\
T3 & 0,116858 & 4 \\
\hline
\end{tabular}

Menurut Safitriani (2014) bahwa ketergantungan Indonesia pada perdagangan internasional sebagai mesin penggerak perekonomian nasional cukup besar. Dari hasil kajian Salomo (2007) diketahui bahwa dalam jangka panjang ekspor berpengaruh signifikan terhadap pertumbuhan ekonomi Indonesia. Kenaikan Ekspor sebesar 1\% cateris paribus, dalam jangka panjang akan meningkatkan Laju Pertumbuhan Ekonomi 0,3\%.

Meningat pentingnya menjaga sistem perdagangan baik nasional/internasional serta guna mendukung target pemerintah untuk meningkatkan ekspor 300\% maka fasilitas perdagangan berupa pengembangan pengembangan pelayanan perijinan berbasis TI menjadi salah satu kuncinya yang perlu dikembangkan.

Penggunaan IT dalam pelayanan perijinan impor hortikultura yang memperingkas birokrasi perijinan diharapkan dapat mempercepat proses dan dapat meningkatkan kelancaran arus barang. Kemudahan dalam fasilitas perdagangan tersebut dikembangkan guna mendukung agar sistem perdagangan baik nasional dan internasional tidak terganggu.

Dalam perdagangan internasional, pemberian fiasilitas perdagangan terhapa produk yang diatur impornya, di satu sisi juga dapat mengurangi resiko terhadap tindakan baIasan dari negara tujuan ekspor/Trade Remedies.

\section{d. Alternatif strategi}

Alternatif strategi yang paling penting dipilih pakar dalam pengembangan Strategi Pengembangan Pelayanan Perijinan Impor Hortikultura Berbasis TI di Kementerian Perdagangan adalah S1 (Mekanisme perijinan terpadu berbasis IT) dengan bobot 0,207167 dan S2 (Monitoring dan evaluasi sistem secara berkala baik dari aspek sistem, SDM dan landasan hukum) dengan bobot 0,142622, sedangkan strategi dengan bobot paling rendah adalah S6 (meningkatkan program reword and punishment bebasis kinerja) dengan bobot 0,052741 .

Tabel 11. Skor bobot alternatif strategi

\begin{tabular}{ccc}
\hline $\begin{array}{c}\text { Alternatif } \\
\text { strategi }\end{array}$ & Bobot & Prioritas \\
\hline S1 & 0,207167 & 1 \\
S2 & 0,142622 & 2 \\
S3 & 0,138434 & 4 \\
S4 & 0,140168 & 3 \\
S5 & 0,089885 & 5 \\
S6 & 0,052741 & 6 \\
\hline
\end{tabular}

Saat ini teknologi informasi dan komunikasi sudah sebuah kebutuhan dalam perdagangan internasional. Berasarkan McMaster (2006) teknologi komunikasi dan informasi merupakan kunci dalam fasilitasi perdagangan. Fasilitas perdagangan bebasis teknologi elektronik menjadi hal yang sangat penting dalam menghadapi peningkatan volume perdagangan internasional yang terus berkembang, karena sistem tradisional yang masih berbasis kertas tidak akan mampu mengatasi peningkatan jumlah transakis perdagangan internasional.

McMaster (2006) mengungkapkan bahwa tujuan utama dari pemanfaatan teknologi elektronik/informasi dalam fasilitasi perdagangan adalah untuk meningkatkan efisiensi dan efektivitas prosedur operasional, aliran dokumentasi dan pertukaran data transaksi perdagangan internasional yang berdampak pada penurunan biaya.

Kompleksitas prosedur perdagangan internasional yang melibatkan lintas lembaga/ 
kementerian seperti Kementerian Pertanian, Badan POM, Kementerian Perdagangan hingga di Bea dan Cukai menjadi lebih mudah ketika mekanisme perijinan dilakukan melalui pendekatan perijinan terpadu berbasis IT.

Stretegi lain yang penting memerlukan perhatian yang lebih adalah monitoring dan evaluasi sistem secara berkala baik dari aspek sistem, SDM dan landasan hukum. Penerapan stategi ini dipandang penting untuk diterapkan mengingat stategi ini akan memotret kebutuhan dan kondisi lapangan sehingga diketahui posisi terkini. Informaisi-informasi tersebut merupakan input yang sangat penting dalam melakukan perencanaan strategis guna melakukan perbaikanperbaikan lebih lanjut.

\section{Implikasi Manajerial}

Dengan penerapan strategi yang diperoleh dari hasil analisis, maka Kementerian Perdagangan mendapatkan beberapa gambaran terhadap potret pelayanan yang telah dilakukan, data base pelaku usaha, profil komoditi dan sistem pelayanan yang baik untuk medukung dalam meningkatkan kecepatan arus barang dan logistik nasional.

Namun demikian ada beberapa tantangan yang harus dihadapi. Salah satu tantangan adalah resisteni petugas dan pelaku usaha yang masih nyaman dengan sistem manual dalam pelayanan perijinan. Direktorat Fasilitasi ekspor dan Impor sebagai vendor pelayanan perijinan berbasis IT, harus terus berupaya untuk mendekatkan diri kepada direktorat teknis lain yang menangani perijinan (Direktorat Impor dan Direktorat Ekspor). Hal ini penting agar proses bisnis yang menggunakan sistem inatrade secara online mudah diadaptasi. Selain itu konsep pendekatan sistem "bottom to top" juga perlu diterapkan agar penerapan berjalan mulus sehingga operator dan pejabat merasakan manfaat sistem ini.

\section{KESIMPULAN}

1. Pelayanan di pelayanan ijin impor di Kementerian Perdagangan, khususnya perijinan produk hortikultura memiliki beberapa kelemahan, yaitu sumber daya penunjang yang kurang memadai, adanya keanekaragaman data/dokumen impor, terjadi resistensi internal terhadap perubahan pola perijinan, kurangnya sosialisasi sistem perijinan online, masalah remunerasi, dan adanya kekakuan alokasi anggaran.

2. Berdasarkan hasil analisa diketahui bahwa faktor yang paling berpengaruh dalam pengembangan stategi pelayanan perijinan impor produh hortikultura adalah organisasi dan SDM, sedangkan aktor yang paling berperan adalah Menteri. Tujuan yang akan

3. Strategi peningkatan mutu pelayanan perijinan yang dapat diambil adalah mekanisme perijinan terpadu berbasis IT serta monitoring dan evaluasi sistem secara berkala baik dari aspek sistem, SDM dan landasan hukum.

\section{DAFTAR PUSTAKA}

David, FR. 2009. Strategic Management: Manajemen Strategis Konsep. Edisi 12. Jakarta: Salemba Empat.

Grainger, A. 2007 "Customs and Trade Facilitation: from Concepts to Implementation", World Customs Journal, Vol. 1 No. 2, 2007.

[Kemendag], Kementerian Perdagangan. 2015 Peraturan Menteri Perdagangan Nomor 30/M-DAG/PER/5/2012 tentang Ketentuan Impor Produk Hortikultura. [Internet]. [diunduh 2014 Januari 10]. Bisa didapat pada http://www.kemendag.go.id/id/news/ 2012/05/10/ketentuan-impor-produkhortikultura

[Kemendag], Kementerian Perdagangan. 2015. Pemberlakuan Mandatory Online Terhadap 96 Perijinan. [internet].[diunduh 2015 Januari 20]. Bisa didapat pada http://inatrade.kemendag.go.id/index.php/h ome/detail_news/86

[Kemendag], Kementerian Perdagangan. 2015. Peraturan Menteri Perdagangan Nomor 53/M-DAG/PER/9/2014 tentang Unit Pelayanan Perdagangan. [Internet]. [diunduh 2015 Januari 30]. Bisa didapat pada http://inatrade.kemendag.go.id/index.php/ perijinan/get_download/182.pdf.

McMaster J. Nowak J, 2006 "The Evolution of Electronic Trade Facilitation: Towards a Global Single Window Trade Portal", tersedia di http://www,researchgate,net/profile/Jan_No wak6/publication/228581401_The_Evolutio n_of_Electronic_Trade_Facilitation_Toward s_a_Global_Single_Window_Trade_Portal/1 inks/0deec52d4fc5617350000000?ev=pub_ex t_doc_dl\&origin=publication_detail\&inVie wer=true [Oktober 2014]. 
Saaty, TL. 1993. Pengambilan Keputusan Bagi Para Pemimpin, Proses Hirarki Analitik untuk Pengambilan Keputusan dalam Situasi yang Kompleks. Pustaka Binama Pressindo.

Safitriani, S. 2014. Perdagangan Internasional dan Foreign Direct Investment di Indonesia, Buletin Ilmiah Litbang Perdagangan, Vol. 8 No. 1 Juli 2014.
Salomo, R M. 2007. Peranan Perdagangan Internasional Sebagai Salah Satu Sumber Pertumbuhan Ekonomi Indonesia, Parallel Session IIID: Trade III (Growth \& FDI), Wisma Makara, Kampus UI-Depok.

[WTO], 1999. The Results of the Uruguay Round of Multilateral Trade Negotiations: The Legal Texts. United Kingdom: Cambridge University Press. 